\title{
Rupture processes and Coulomb stress changes of the 2017 Mw 6.5 Jiuzhaigou and 2013 Mw 6.6 Lushan earthquakes
}

\author{
Xin Lin, Risheng Chu and Xiangfang Zeng*
}

\begin{abstract}
Since the 2008 great $M_{w} 7.9$ Wenchuan earthquake, two destructive earthquakes, the $2013 M_{w} 6.6$ Lushan earthquake and the $2017 M_{w} 6.5$ Jiuzhaigou earthquake, struck the eastern margin of the Tibetan Plateau, causing many casualties and significant property damage. The rupture processes and Coulomb stress change of the Lushan and Jiuzhaigou earthquakes are investigated in this study. The general patterns of the slip models of the two events are similar, where the slip is concentrated around the hypocenter and the primary ruptured zone extends about $20 \mathrm{~km}$ along strike. The rupture zone of the 2017 Jiuzhaigou earthquake spans a depth range of 4-16 km with a peak slip of $\sim 115 \mathrm{~cm}$, whereas the rupture zone of the 2013 Lushan earthquake is concentrated at 8 to $20 \mathrm{~km}$ depth with a peak slip of $125 \mathrm{~cm}$. The coseismic static Coulomb stress changes induced by the two events are computed with the obtained slip models. The Tazang fault and the northern extremities of the Minjiang and Huya faults were strongly loaded by the Jiuzhaigou earthquake, whereas the Lushan earthquake mainly affected its surrounding faults. Therefore, we infer that the seismic hazard potential in these regions has probably been increased further, and the Lushan earthquake did not contribute significantly the occurrence of the Jiuzhaigou earthquake. Additionally, we also compute the stress changes imparted by the 2008 Wenchuan earthquake. The computed stress changes in both events' hypocenters exceed the trigger threshold $(0.1 \mathrm{bar})$, which suggests that the Wenchuan earthquake played a pivotal role in the occurrence of these two earthquakes.
\end{abstract}

Keywords: 2017 Jiuzhaigou earthquake, 2013 Lushan earthquake, Waveform inversion, Finite-fault model, Coulomb stress change

\section{Introduction}

On May 12, 2008, the disastrous $M_{\mathrm{w}} 7.9$ Wenchuan earthquake occurred on the central-northern segments of the Longmen Shan fault zone near the eastern margin of the Tibetan Plateau. The earthquake caused large ground deformations and accumulation of stresses in a wide area (Parsons et al. 2008; Toda 2008; Shen et al. 2009; Hashimoto et al. 2010; Luo and Liu 2010; Wan and Shen 2010; Nalbant and Mccloskey 2011; Wang et al. 2011; Zhang et al. 2015), resulting in nearly 70,000 fatalities and destroying millions of buildings (http:// www.cctv.com/english/special/earthquake/01/index

*Correspondence: zengxf@whigg.ac.cn

State Key Laboratory of Geodesy and Earth's Dynamics, Institute

of Geodesy and Geophysics, Chinese Academy of Sciences, Wuhan, China .shtml). Later on, two strong earthquakes, the 2013 $M_{\mathrm{w}} 6.6$ Lushan and the $2017 M_{\mathrm{w}} 6.5$ Jiuzhaigou earthquakes struck the eastern margin of the Tibetan Plateau and induced many casualties and significant property damage (https://reliefweb.int/disaster/eq-2013-00004 6-chn; https://edition.cnn.com/2017/08/08/asia/china -earthquake/index.html). The Jiuzhaigou earthquake is dominated by a strike-slip component and occurred in a complex tectonic area where mainly suffering the collision and extrusion of the India plate to the Eurasia plate. The earthquake took place about $250 \mathrm{~km}$ northwest of the Wenchuan earthquake, whereas the Lushan earthquake occurred on the southern segment of the Longmen Shan fault zone (Fig. 1). Xie et al. (2018) investigated the rupture process, and the Coulomb stress change of the Jiuzhaigou earthquake, but 


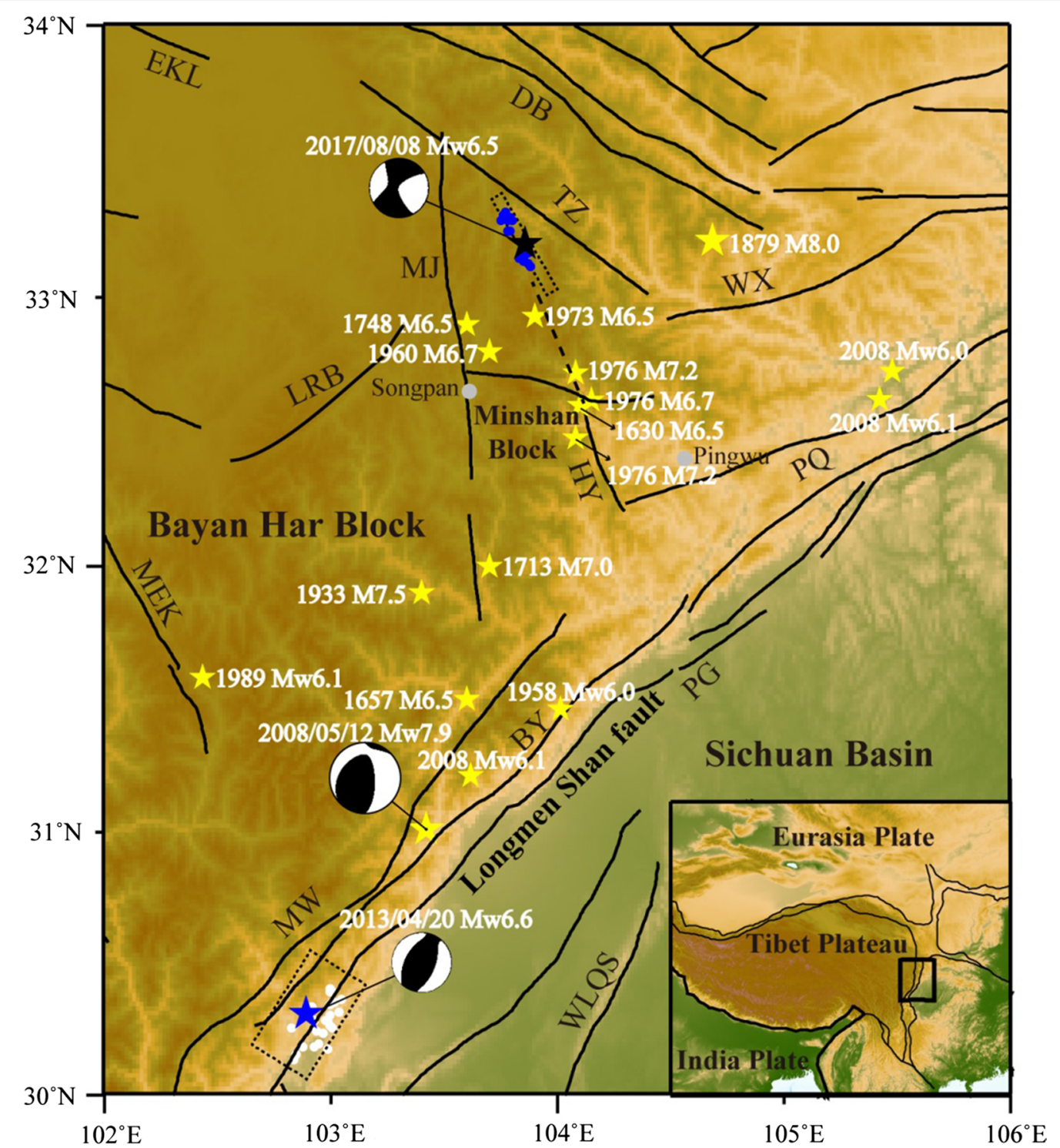

Fig. 1 Tectonic settings of the eastern margin of the Tibet Plateau region. Black star, blue star and yellow stars represent the epicenters of the 2017 Jiuzhaigou earthquake, 2013 Lushan earthquake and historical earthquakes, respectively. The blue circles are the 2017 Jiuzhaigou earthquake 1 day $M_{L}>3$ aftershocks, and white circles denote the 2013 Lushan earthquake 1 day $M_{L}>4$ aftershocks. The black dash boxes indicate the surface projection of the fault planes used in this study. Focal mechanisms of the 2008 Wenchuan, 2017 Jiuzhaigou and 2013 Lushan earthquakes are also plotted (http://www.globalcmt.org/CMTsearch.html). The inset shows the local tectonic setting. The black lines indicate the major active faults in this region according to Deng et al. (2003a): BY (Beichuan-Yinxiu), DB (Diebu-Bailongjiang), EKL (East Kunlun), HY (Huya), LMS (Longmen Shan), LRB (Longriba), MEK (Maerkang), MJ (Minjiang), MW (Maowen-Wenchuan), PG (Pengxian-Guanxian), PQ (Pingwu-Qingchuan), TZ (Tazang), WLQS (West-Longquanshan) and WX (Wenxian) faults. Location parameters of historical earthquakes are based on the previous studies (Jones et al. 1984; Department of Earthquake Disaster Prevention, China Earthquake Adiministration 1995, 1999; USGS, https://earthquake.usgs.gov/). The thin black lines in the inset map of Fig. 1 are boundaries of first-level blocks in mainland China, and the bold black lines 1 are boundaries of plates

did not analyze the connection between the Wenchuan earthquake and the Jiuzhaigou earthquake. The connections between these three events and their effects on the regional seismic hazard have attracted wide interest, and most studies (e.g., $\mathrm{Hu}$ et al. 2017; Han et al. 2018; Jia et al. 2018) have been based on computing the
Coulomb stress change, which has been widely used in past decades (King et al. 1994; Toda et al. 1998).

The Coulomb stress change induced by an earthquake is a quantitative measure of the aftershock distribution, seismicity rate changes and earthquake triggering (Das and Scholz 1981; Stein and Lisowski 1983; Reasenberg 
and Simpson 1992; Stein et al. 1992; Hill et al., 1993; Bouchon 1997; Barka 1999; Stein 1999; Pollitz et al. 2003; Tibi et al. 2003; Lin and Stein 2004; Freed 2005; Helmstetter et al. 2005; Nostro et al. 2005; Steacy et al. 2005; Zhuang et al. 2005; Parsons et al. 2006; Huang 2008; Toda 2008b; Hainzl et al. 2010; Xiong et al. 2010; Toda et al. 2012; Ishibe et al. 2015). Most aftershocks occur in the high-stress region, and seismicity rates fall with stress. A stress change of 0.1 bar is usually considered the threshold value of earthquake triggering (King et al. 1994; Harris 1998; Ma et al. 2005).

The Coulomb stress changes induced by the Wenchuan, Lushan and Jiuzhaigou earthquakes and the relationships among these events have been investigated by several groups with various slip models (e.g., Parsons et al. 2008; Toda et al. 2008; Luo and Liu 2010; Xu et al. 2010). However, some issues remain controversial. For example, the Coulomb stress increases in some areas suggesting that the Wenchuan earthquake promoted the Jiuzhaigou earthquake (Toda et al. 2008; Shan et al. 2017; Wang and Xu 2017), while in other regions the stress change is negatively contradicting this conclusion (Parsons et al. 2008; Nalbant and McCloskey 2011; Jia et al. 2018). To clarify those issues, it is necessary to examine more extensive and comprehensive information on the slip model and the receiver fault used to calculate the Coulomb stress change. The relatively reliable source model is a key to calculate the Coulomb stress change. Moreover, the nodal plane of the Wenchuan earthquake is often used as the receiver fault to calculate its impact on the hypocenters of the Jiuzhaigou and Lushan earthquakes (e.g., Xie et al. 2010; Shan et al. 2013).

In this paper, we explore the relationships among the Wenchuan earthquake, the Jiuzhaigou earthquake and the Lushan earthquake using teleseismic data. We test the focal mechanism solutions given by different institutions, such as GCMT, USGS and China Earthquake Networks Center (CENC) and apply the best-fits in finite-fault inversion of Jiuzhaigou and Lushan earthquakes. Using the inverted slip models, we then calculate coseismic static Coulomb stress changes and discuss the correlation with aftershock distribution, in addition, estimating the impact of the stress changes on the nearby active faults. Finally, we use the fault planes of the Jiuzhaigou and Lushan earthquakes as receiver faults calculating the stress effects of the Wenchuan earthquake and discuss the relationship with the Jiuzhaigou and Lushan earthquakes.

\section{Tectonic settings}

The eastern margin of the Tibet Plateau is composed of the Minshan block and Longmen Shan fault zone, situated in the deformation zone created by the ongoing collision and extrusion of the India plate to the Eurasia plate in the NNE direction, featuring several large active faults, such as the Longmen Shan fault and the Minjiang fault (Burchfiel et al. 1995). With strong uplift in the NS direction since the Quaternary, the Minshan block is located in the central segment of the north-south seismic zone in China, and it is bounded by the Minjiang and Huya faults on the west and east, respectively. The southern and northern margins are intersected by the Longmen Shan fault zone and the Tazang fault, respectively. Geological and geophysical studies have indicated that the Huya fault is dominated by reverse slip movement with a minor left-lateral strike-slip component as well as the Minjiang fault due to the regional main compressive stress field in the WNW direction (Kirby et al. 2000; Zhou et al. 2000). Located at the east section of the East Kunlun fault, the NE-trending Tazang fault is a Holocene active fault, and presents left-lateral and thrust movements in its western and eastern segment, respectively, due to the compressive shear stress (Zhang et al. 2012). In addition, the Longmen Shan fault zone, which shows a thrust motion from south to north, can be divided into three main faults: the Maowen-Wenchuan fault (southern segment, MW), the Beichuan-Yinxiu fault (central segment, BY) and the Pengxian-Maoxian fault (northern segment, PG) (Zhu et al. 2008).

This region has a long history of massive earthquakes and has produced dozens of destructive earthquakes over the past several centuries (Fig. 1). It is clear that the Minshan area is seismically active due to the regional block (such as Bayan Har block) gliding toward the ESE direction (Chen et al. 2000). In August 1976, the Songpan-Pingwu region, around $50 \mathrm{~km}$ southeast of the 2017 Jiuzhaigou earthquake, was struck by three large earthquakes of M7.2, M6.7 and M7.2. Earlier, it had experienced the 1933 M7.5 Diexi, the 1960 M6.7 Zhangla and the 1973 M6.5 Huanglong earthquakes. Due to these crisscrossing active faults and destructive earthquakes, the eastern margin of the Tibet Plateau has already become one of the most active tectonic areas in China.

\section{Methods}

Finite-fault inversion methods have been developed over the last 40 years to study the rupture process of large earthquakes, from which we can obtain the detailed mapping of the slip distribution using teleseismic broadband waveform (Olson and Apsel 1982; Hartzell and Heaton 1983; Hartzell and Liu 1996; Ji et al. 2002; Wang et al. 2004; Lay et al. 2010; Wei et al. 2013; Avouac et al. 2014; Yagi et al. 2016; Ye et al. 2016). Ji et al. (2002) proposed a waveform inversion approach using wavelet transform and a simulated annealing algorithm, in which the parameters of each 
subfault, such as the slip amplitude, the slip direction, the rake angle, the rupture velocity and the slip rate function, can be inverted simultaneously. In addition, to stabilize the inversion, a temporal constraint is applied to compress the roughness of the rupture front (Shao et al. 2011). By taking into consideration the characteristics in both the time and frequency domains, this approach is suitable for different scales of seismic waveforms providing high resolution. In this study, we adopt this wavelet analysis method (Ji et al. 2002, 2003; Shao et al. 2011) to invert the rupture processes of the 2017 Jiuzhaigou and 2013 Lushan earthquakes using teleseismic body and surface waves.

Based on the Coulomb criterion and focal mechanism theory, the Coulomb failure function can be defined as

$$
\Delta \mathrm{CFF}=\Delta \tau+\mu(\Delta \sigma n+\Delta P),
$$

where $\Delta \tau$ and $\Delta \sigma n$ represent the shear stress change (calculated in slip direction) and the fault-normal stress change (positive for unclamping), respectively. $\Delta P$ is the pore pressure change within the fault, and $\mu$ is the friction coefficient.

Under undrained conditions, the pore pressure change is calculated by (Rice and Cleary 1976; Cocco and Rice 2002)

$$
\Delta P=-B \frac{\Delta \sigma i i}{3},
$$

where $B$ is the Skempton coefficient, and $\Delta \sigma i i$ is the stress tensor. If $\Delta \sigma n=\frac{\Delta \sigma i i}{3}$ in the fault zone, then we can calculate the Coulomb stress changes as

$$
\Delta \mathrm{CFF}=\Delta \tau+\mu^{\prime} \Delta \sigma n,
$$

where $\Delta \tau, \Delta \sigma n$ and $\mu^{\prime}\left(\mu^{\prime}=(1-\mathrm{B}) \cdot \mu\right)$ are the shear stress change, the normal stress change and the effective friction coefficient, respectively. The values for the effective friction coefficient range from 0.0 to 0.8 , while 0.4 has been widely used in calculations (Stein et al. 1992; King et al. 1994). Here, we calculate the Coulomb stress changes using the inverted slip models following the approach (Okada 1992) that gives a complete set of closed analytical expressions for the internal displacements and strains fields in an elastic half-space.

\section{Results}

Rupture process of the 2017 Jiuzhaigou earthquake

In this study, we select the epicenter location $\left(33.20^{\circ} \mathrm{N}\right.$, $\left.103.85^{\circ} \mathrm{E}\right)$ reported by USGS. Focal mechanisms of the 2017 Jiuzhaigou earthquake are shown in Table 1. The broadband waveform data are downloaded from the data center of Incorporated Research Institutions for Seismology (IRIS). After removing the instrument responses, we use a well-distributed teleseismic dataset comprised of $18 \mathrm{P}$-wave, $12 \mathrm{SH}$-wave and 32 surface-wave waveforms with good azimuthal coverage and high signal-to-noise ratios at the epicentral distances of $30^{\circ}$ to $90^{\circ}$. Band-pass filters with frequency bands between 0.003 and $1.0 \mathrm{~Hz}$ are applied to the body waves, while surface waves are filtered in $0.004-0.006 \mathrm{~Hz}$ (Hao et al. 2013). The velocity structure in the source region is extracted from the Crust 2.0 model (Bassin et al. 2000) and PREM model (Dziewonski and Anderson 1981). To calculate the teleseismic body-wave and surface-wave synthetic seismogram, we used the generalized ray theory and normal mode theory, respectively. We adopt a $45 \mathrm{~km}$ (along strike) $\times 20 \mathrm{~km}$ (downdip) rectangular fault plane to invert the spatial and temporal slip distribution, which is subdivided into 150 $3.0 \mathrm{~km} \times 2.0 \mathrm{~km}$ subfaults. During the inversions, we vary the slip amplitude from 0 to $2.0 \mathrm{~m}$ and let the starting and ending times of the slip rate functions range between 0.2 and $1.2 \mathrm{~s}$, while the value of the rise time varies from 0.4 to $2.4 \mathrm{~s}$ (Hao et al. 2013). In addition, we limit the rake angle between the reference value $(\lambda$ in Table 1$)$ of $\pm 30^{\circ}$ and the rupture velocity in the range of $0.75-3.5 \mathrm{~km} / \mathrm{s}$. A grid searching for the rupture initiation depth is applied to ensure the accuracy of the inversion. After testing the different focal mechanisms, we select the nodal plane 2 $\left(\phi=150^{\circ}, \delta=78^{\circ}, \lambda=-13^{\circ}\right)$ given by GCMT as the causative fault plane, and the rupture with initiation depth of $9.0 \mathrm{~km}$ can produce the best-fits (Additional file 1: Figures $\mathrm{S} 1$ and $\mathrm{S} 3$ ).

The results are summarized in Fig. 2. Due to the leftlateral strike-slip fault event with a high dip angle, rupture on the main fault plane has a concentrated slip distribution with no obvious horizontal directivity. The large-slip patch extends $\sim 20 \mathrm{~km}$ along strike and a depth range of 4-16 km with $\sim 115 \mathrm{~cm}$ peak slip near

\begin{tabular}{|c|c|c|c|c|c|c|c|}
\hline & \multicolumn{3}{|c|}{ Nodal plane 1} & \multicolumn{3}{|c|}{ Nodal plane 2} & \multirow[t]{2}{*}{ Depth (km) } \\
\hline & Strike/ $\varphi$ & $\mathrm{Dip} / \delta$ & Rake/入 & Strike/ $\varphi$ & Dip/ $\delta$ & Rake/ $\lambda$ & \\
\hline USGS & $246^{\circ}$ & $57^{\circ}$ & $-173^{\circ}$ & $153^{\circ}$ & $84^{\circ}$ & $-33^{\circ}$ & 9 \\
\hline GCMT & $242^{\circ}$ & $77^{\circ}$ & $-168^{\circ}$ & $150^{\circ}$ & $78^{\circ}$ & $-13^{\circ}$ & 14.9 \\
\hline CENC & $64^{\circ}$ & $77^{\circ}$ & $-151^{\circ}$ & $326^{\circ}$ & $62^{\circ}$ & $-15^{\circ}$ & 11 \\
\hline
\end{tabular}
the hypocenter. Most of the rupture slips are released

Table 1 Focal mechanism of the 2017 Jiuzhaigou earthquake 

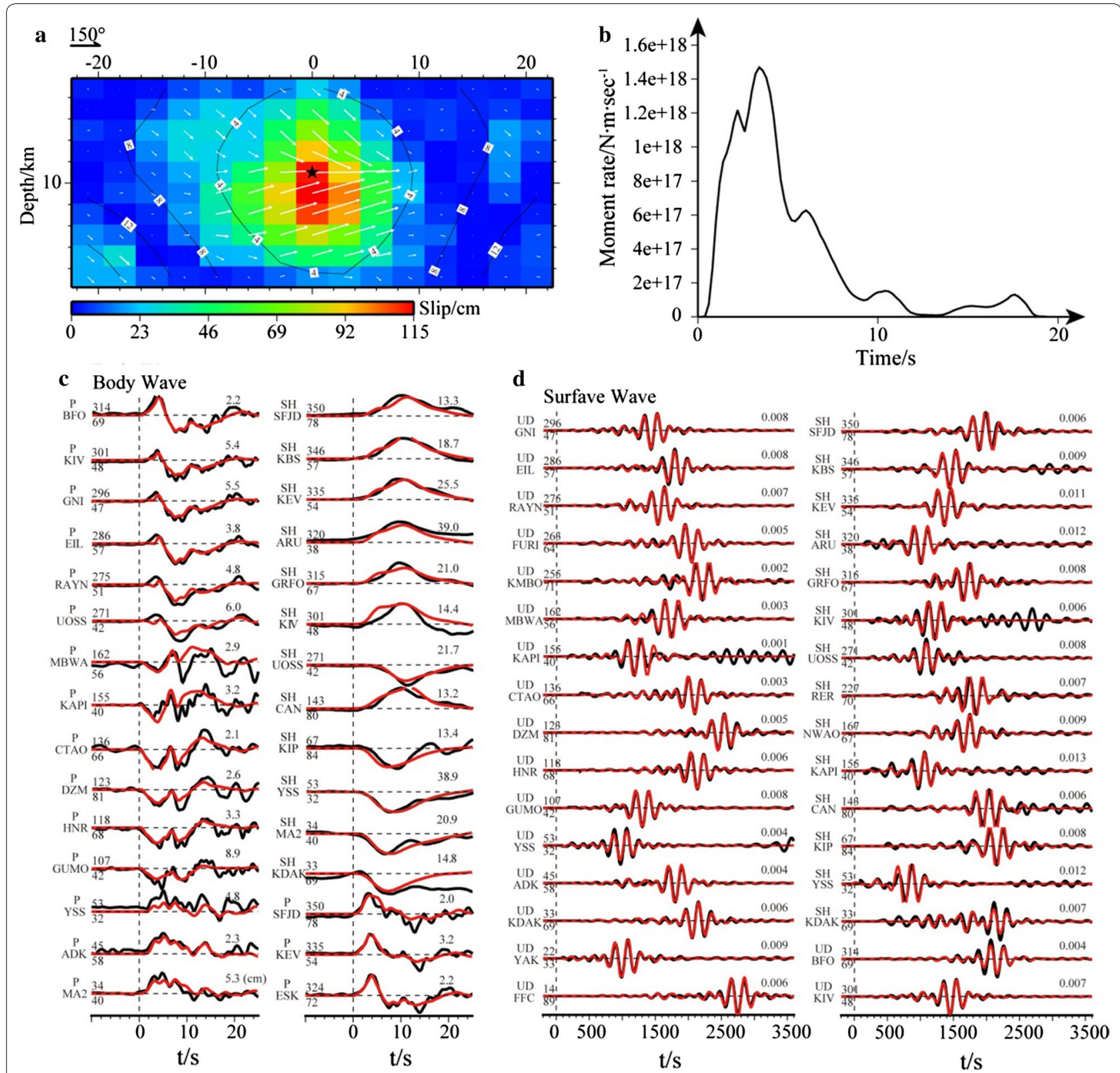

Fig. 2 Inversion results of the 2013 Lushan earthquake. a Slip distribution on the fault plane, the star represents the epicenter, the size and direction of the arrows represent the slip size and slip direction, the number is the rupture propagation time. $\mathbf{b}$ Scalar seismic moment rate evolution versus time. $\mathbf{c}$ Match of observed teleseismic body waves and synthetic waveforms; $\mathbf{d}$ match of observed teleseismic surface waves and synthetic waveforms, the black line and red line indicate the observed record and synthetic seismogram, the station, azimuth, epicentral distance and the maximum in observation (in $\mathrm{cm}$ ) are also plotted

within the first $15 \mathrm{~s}$. In addition, the rupture initiates at the hypocenter, then spreads rapidly away (rupture velocity about $2.1 \mathrm{~km} / \mathrm{s}$ ) and decreases as the distance from the hypocenter increases. We obtain a total seismic moment of $6.86 \times 10^{18} \mathrm{Nm}$, equivalent to an $M_{\mathrm{w}} 6.5$ earthquake (Kanamori, 1977).
Rupture process of the 2013 Lushan earthquake

Likewise, the fault plane is parameterized with 19 subfaults along the strike and 15 subfaults along the dip, with $2.5 \mathrm{~km} \times 2.5 \mathrm{~km}$ subfault dimensions, and the total fault dimensions are $47.5 \mathrm{~km} \times 37.5 \mathrm{~km}$. We utilize a teleseismic dataset of $19 \mathrm{P}$-wave, $6 \mathrm{SH}$-wave and 27 surface-wave 
waveforms to perform the inversion process after removing the instrument responses. All parameters (e.g., frequency band, velocity model, etc.) are the same as ones used in the 2017 Jiuzhaigou earthquake inversion. We choose the epicenter location $\left(30.31^{\circ} \mathrm{N}, 102.89^{\circ} \mathrm{E}\right)$ reported by USGS and nodal plane $2\left(\phi=212^{\circ}, \delta=42^{\circ}\right.$, $\lambda=100^{\circ}$ ) given by GCMT (Table 2) as the causative fault plane (Additional file 1: Figure S2). Moreover, the grid searching for the rupture initiation depth of about $14.4 \mathrm{~km}$ provides the best-fit (Additional file 1: Figure S4).

The slip distribution, moment rate function and fitting results of teleseismic waveforms are shown in Fig. 3. The differences between the observed teleseismic surface waves and the synthetic waveforms of the $\mathrm{SH}$ waves may be related to the dip angle that is close to $45^{\circ}$, which excites the $\mathrm{SH}$ waves less favorably. We can see that the Lushan earthquake is a thrust event, with slip concentrated around the hypocenter. The slip distribution of the fault plane is dominated by a primary slip zone that spans about $20 \mathrm{~km}$ along strike with a depth range from 8 to $20 \mathrm{~km}$, and the peak slip is $\sim 125 \mathrm{~cm}$. The main rupture occurs during the first $10 \mathrm{~s}$, followed by two sub-events after $\sim 14 \mathrm{~s}$, with an average rupture velocity of $\sim 2.0 \mathrm{~km} / \mathrm{s}$. The estimated seismic moment is $9.18 \times 10^{18} \mathrm{Nm}\left(M_{\mathrm{w}}=6.6\right)$.

\section{Static Coulomb stress change of the 2017 Jiuzhaigou earthquake}

To calculate coseismic static Coulomb stress change induced by the 2017 Jiuzhaigou earthquake, we use the inverted slip model and assume a receiver fault with a strike of $150^{\circ}$, a dip of $78^{\circ}$ and a rake of $-15^{\circ}$, which is also the ruptured fault. The effective friction coefficient ranges between 0.0 and 0.8 for most faults. Here, we apply $\mu^{\prime}=0.4$ for the calculations. We adopt the catalogs of aftershocks from CENC (Tables 3 and 4) and make the cross section (Additional file 1: Fig. S5) which is perpendicular to the strike of the source fault using relocated aftershocks of the 2013 Lushan earthquake from Han et al. (2014). The aftershock catalog contains the list of aftershocks we used in the text (Table 4). Considering the result of depth cross section (Additional file 1: Fig. S5b and Han et al. 2018), we assume that all aftershocks listed in the tables are located on-fault or parallel to the source fault. We calculated the stress changes imparted by the 2017 Jiuzhaigou earthquake at different depths (Fig. 4). It shows that most aftershocks are located in the stress-decreased regions at shallow depths. It is not uncommon to find that aftershocks occurred in regions with calculated stress decrease (Parsons and Segou, 2014). Moreover, we computed the static stress change for each aftershock (Table 3) and plotted histogram of aftershocks as the function of the value of static stress change (Additional file 1: Fig. S6a). It is noted that there are several factors might affect the stress change for each aftershocks, such as depth and/or horizontal location uncertainties of aftershocks, large stress drop appeared at the edge of large rupture zone and the initial stress and the fault strength (e.g., Ogata, 2005).

We subsequently computed stress changes on the nearby active faults caused by the Jiuzhaigou earthquake, and the parameters of the receiver faults are listed in Table 5 (refers to Parsons et al. 1999; Deng et al. 2003b; Kirby et al. 2007; Ren et al. 2013). In our calculation, we divided the fault into one or multi-segment based on the historical data, calculated the stress change on the fault plane, and plotted the distribution of changes within the dip range. The effective friction coefficient $\mu$ ' is often selected based on empirical value and relatively small where the fault has a large-slip accumulation (Parsons et al. 1999; He and Chéry 2008). To test the change, we selected the different effective friction coefficient of 0.1 and 0.4 for Tazang fault and calculated the stress changes, respectively. Results show that the increment of stress change in $\mu^{\prime}=0.4$ is about $5 \%$ larger than $\mu^{\prime}=$ 0.1 . It may be the fact that shear stress changes on Tazang fault are larger than the normal stress and the Coulomb stress on the fault does not change much. To obtain reliable results, more information (e.g., geology and tectonics) are needed in stress change calculation to constrain the uncertainty range of fault parameters, which is also our goal in the future.

Results indicate that several active faults around the epicentral area are strongly stressed, such as the Tazang fault, and the northern extremities of the Minjiang and Huya faults, where stress has increased by $0.24,0.1$ and 0.18 bar, respectively. On the other hand, there is almost

Table 2 Focal mechanism of the 2013 Lushan earthquake

\begin{tabular}{|c|c|c|c|c|c|c|c|}
\hline & \multicolumn{3}{|c|}{ Nodal plane 1} & \multicolumn{3}{|c|}{ Nodal plane 2} & \multirow[t]{2}{*}{ Depth (km) } \\
\hline & Strike/ $\varphi$ & $\mathrm{Dip} / \delta$ & Rake/ $\lambda$ & Strike/ $\varphi$ & Dip/ $\delta$ & Rake/ $\lambda$ & \\
\hline USGS & $218^{\circ}$ & $39^{\circ}$ & $103^{\circ}$ & $22^{\circ}$ & $52^{\circ}$ & $80^{\circ}$ & 14 \\
\hline GCMT & $212^{\circ}$ & $42^{\circ}$ & $100^{\circ}$ & $19^{\circ}$ & $49^{\circ}$ & $81^{\circ}$ & 21.9 \\
\hline CENC & $214^{\circ}$ & $39^{\circ}$ & $100^{\circ}$ & $21^{\circ}$ & $48^{\circ}$ & $-136^{\circ}$ & 19 \\
\hline
\end{tabular}



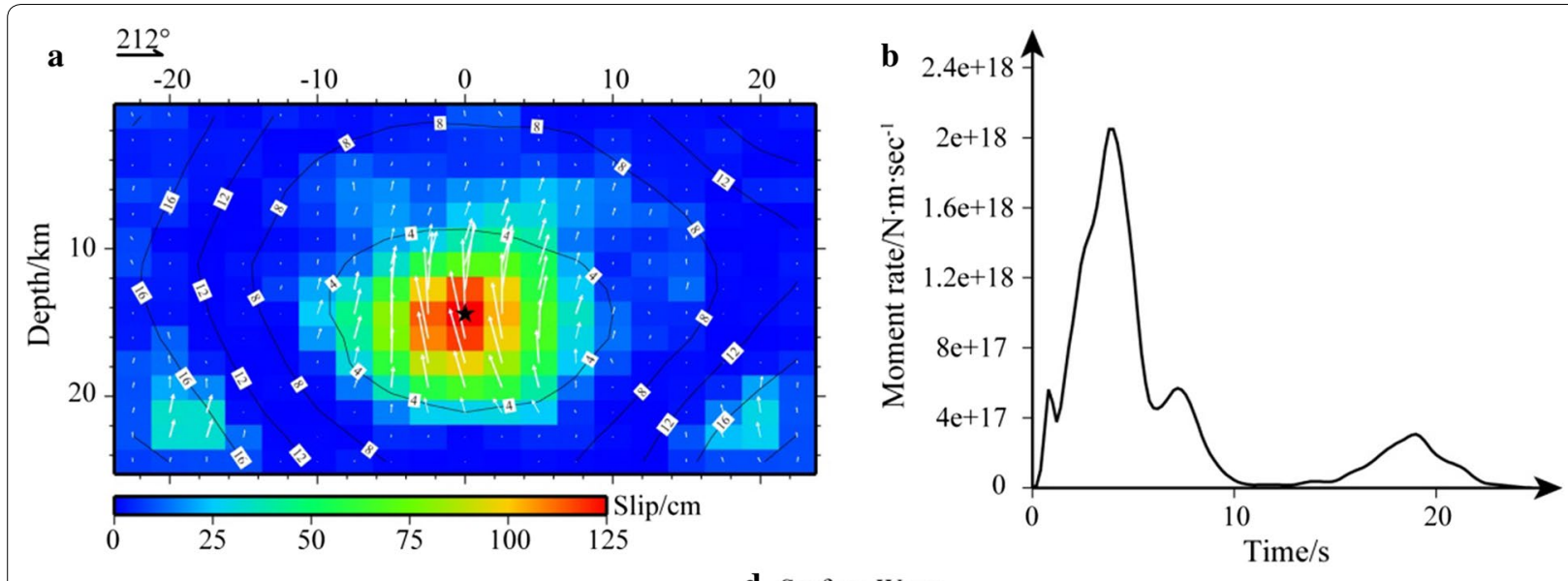

c

d Surfave Wave
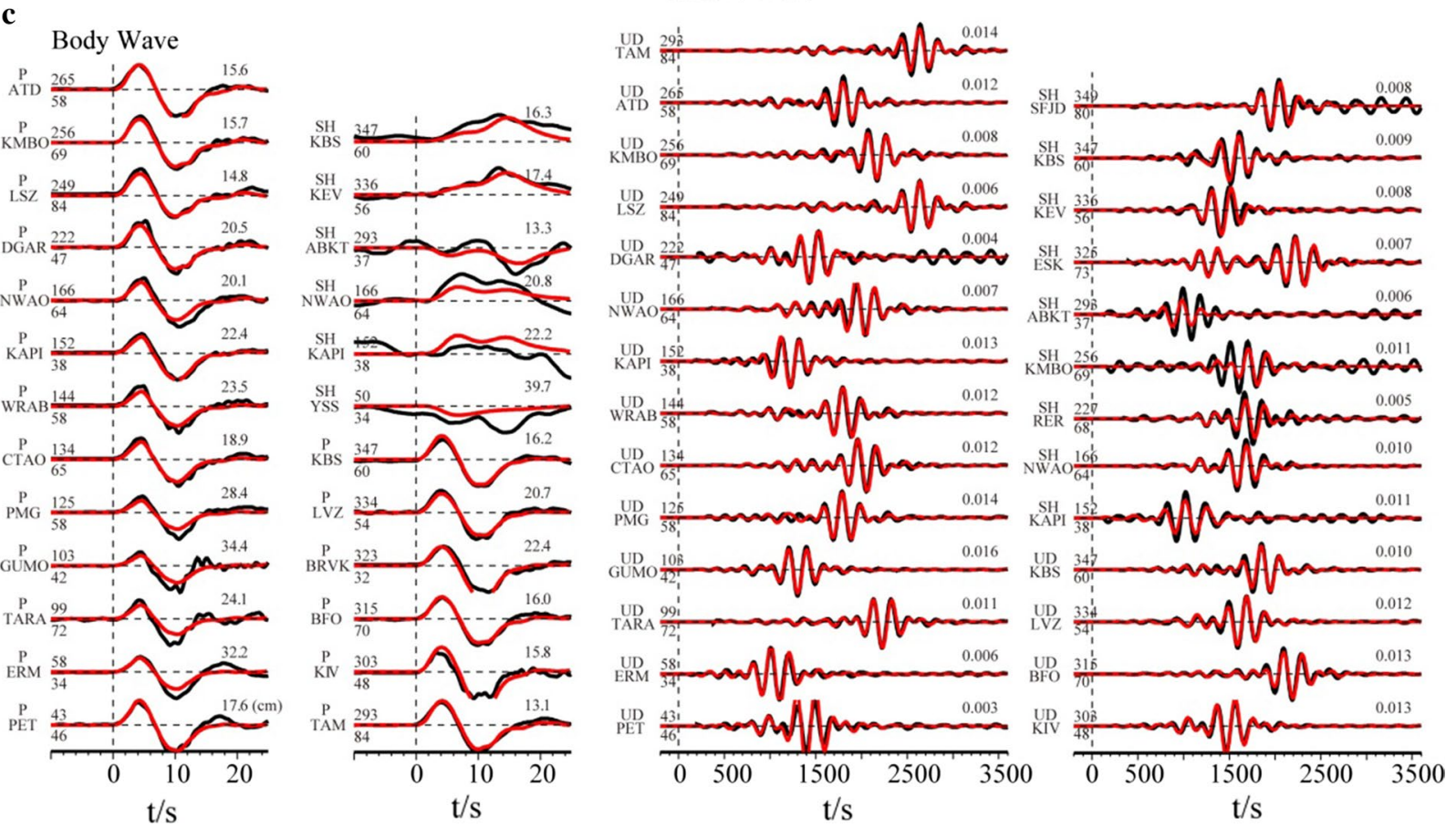

Fig. 3 Inversion results of the 2013 Lushan earthquake. a Slip distribution on the fault plane, the star represents the epicenter, the size and direction of the arrows represent the slip size and slip direction, the number is the rupture propagation time. $\mathbf{b}$ Scalar seismic moment rate evolution versus time. c Match of observed teleseismic body waves and synthetic waveforms. $\mathbf{d}$ Match of observed teleseismic surface waves and synthetic waveforms, the black line and red line indicate the observed record and synthetic seismogram, the station, azimuth, epicentral distance and the maximum in observation (in $\mathrm{cm}$ ) are also plotted

no impact on the major active faults away from the epicentral area (Fig. 5a).

\section{Static Coulomb stress change of the 2013 Lushan earthquake}

Similarly, we calculate the stress change caused by the 2013 Lushan earthquake (Fig. 6, Additional file 1: Figures S6b and S7) and assess the effects of stress on the adjacent faults (Fig. 5b). The parameters of the receiver fault are strike $212^{\circ}$, dip $42^{\circ}$ and rake $94^{\circ}$, the same as for the ruptured fault. Our results reveal that Coulomb stress increased in the epicentral area by more than 0.3 bar. This also affected the adjacent faults, in the western extremities of the MW, BY and PG faults, where stress increased by more than $0.07,0.11$ and 0.26 bar, respectively. Furthermore, most of the 26 aftershocks above $\mathrm{M}_{\mathrm{L}} 4$ (Table 4) that occurred within $24 \mathrm{~h}$ after the mainshock occurred in the high-stress regions, whereas few 
Table 3 Catalog of the 2017 Jiuzhaigou aftershocks from CENC

\begin{tabular}{llllc}
\hline Longitude $^{\circ}$ & Latitude/ $^{\circ}$ & Depth $(\mathbf{k m})$ & Magnitude & CFS (bar) \\
\hline 103.87 & 33.16 & 24 & 3.1 & 1.915 \\
103.86 & 33.16 & 26 & 4.8 & 1.221 \\
103.75 & 33.28 & 19 & 3.7 & -0.291 \\
103.85 & 33.16 & 19 & 3.8 & 0.154 \\
103.8 & 33.28 & 13 & 3.9 & -9.129 \\
103.87 & 33.12 & 23 & 3.7 & 2.189 \\
103.77 & 33.31 & 13 & 3.3 & 5.541 \\
103.88 & 33.11 & 18 & 3.2 & 2.462 \\
103.85 & 33.14 & 18 & 3 & 0.25 \\
103.83 & 33.14 & 10 & 3.3 & -9.895 \\
103.87 & 33.12 & 17 & 3.6 & -1.684 \\
103.76 & 33.3 & 10 & 3.6 & -0.348 \\
103.79 & 33.29 & 10 & 3 & -4.099 \\
103.85 & 33.13 & 20 & 3.2 & 1.33 \\
103.88 & 33.11 & 10 & 3.1 & -7.29 \\
103.78 & 33.28 & 9 & 3 & -3.061 \\
103.79 & 33.24 & 5 & 3.2 & -2.781 \\
103.85 & 33.18 & 9 & 3.3 & -7.867 \\
103.78 & 33.24 & 5 & 3.2 & -2.222 \\
\hline
\end{tabular}

occurred in the low-stress regions (Fig. 6). In addition, the two largest aftershocks (M 5.4) within $24 \mathrm{~h}$ located in region with positive stress change (Fig. 6c). To illustrate the depth variation, we computed the maximum stress changes and constructed a cross section along the rupture (Additional file 1: Fig. S7). The triggering effect generally depends on the increment of the maximum Coulomb stress on the fault plane (Lin and Stein 2004). Results show that the Coulomb stress-increased regions are mainly concentrated in the range of 5-20 km (Additional file 1: Fig. S7b), and most aftershocks in the catalog (Table 4) occurred within this depth range as well. The occurrence of aftershocks may be affected by a variety of factors, such as cascade triggering (Marsan and Lengline 2008), slip solutions (Steacy et al. 2004) and stress heterogeneity (Helmstetter and Shaw 2006). Therefore, our conclusion is that the Coulomb stress change shows a good correlation with the aftershock distribution on this occasion. In contrast, stress changes on the remote faults around the epicentral area of the Jiuzhaigou earthquake are almost negligible $(<0.001 \mathrm{bar})$.

\section{Impact of the $\mathbf{2 0 0 8}$ Wenchuan earthquake} on the Jiuzhaigou and Lushan earthquakes

To investigate the impact of the Wenchuan earthquake on the Jiuzhaigou and Lushan earthquakes, we use the well-determined velocity and slip models (modified
Table 4 Catalog of the 2013 Lushan aftershocks from CENC

\begin{tabular}{|c|c|c|c|c|}
\hline Longitude/ ${ }^{\circ}$ & Latitude/ ${ }^{\circ}$ & Depth (km) & Magnitude & CFS (bar) \\
\hline 102.88 & 30.18 & 10 & 4.2 & -0.22 \\
\hline 102.92 & 30.32 & 10 & 5.0 & -8.905 \\
\hline 103.01 & 30.39 & 12 & 4.0 & 2.684 \\
\hline 102.93 & 30.18 & 19 & 4.0 & 1.019 \\
\hline 102.93 & 30.28 & 15 & 4.8 & -3.423 \\
\hline 102.83 & 30.25 & 16 & 4.7 & -1.44 \\
\hline 102.99 & 30.17 & 19 & 4.8 & 0.397 \\
\hline 102.95 & 30.19 & 17 & 4.6 & 0.678 \\
\hline 102.99 & 30.28 & 15 & 4.9 & -0.956 \\
\hline 102.84 & 30.13 & 17 & 4.7 & 0.554 \\
\hline 102.92 & 30.33 & 15 & 4.3 & -9.22 \\
\hline 103.01 & 30.25 & 17 & 4.7 & 0.092 \\
\hline 102.94 & 30.24 & 15 & 5.4 & -0.322 \\
\hline 103.00 & 30.39 & 17 & 4.2 & 1.446 \\
\hline 103.04 & 30.31 & 17 & 4.0 & 0.064 \\
\hline 103.00 & 30.40 & 17 & 4.1 & 1.393 \\
\hline 103.02 & 30.35 & 17 & 4.3 & 0.719 \\
\hline 102.85 & 30.15 & 10 & 4.0 & 2.816 \\
\hline 103.01 & 30.35 & 19 & 4.0 & 1.003 \\
\hline 102.97 & 30.23 & 15 & 4.0 & -0.243 \\
\hline 103.05 & 30.36 & 27 & 5.0 & 0.464 \\
\hline 103.00 & 30.26 & 17 & 4.9 & 0.146 \\
\hline 103.00 & 30.34 & 17 & 5.4 & 0.717 \\
\hline 102.98 & 30.28 & 18 & 4.3 & 0.617 \\
\hline 103.00 & 30.30 & 18 & 4.2 & 0.476 \\
\hline 102.90 & 30.30 & 18 & 4.4 & -8.551 \\
\hline
\end{tabular}

from Ji and Hayes 2008; http://earthquake.usgs.gov/ eqcenter/eqinthenews/2008/us2008ryan/finite_fault .php) and select the nodal planes of the Jiuzhaigou and Lushan earthquakes as the receiver fault to calculate the coseismic Coulomb stress changes at the depths of 9 and $14.4 \mathrm{~km}$ with an effective friction coefficient of 0.4 (Fig. 7). Our results show that the Wenchuan earthquake increased the stress up to 0.13 bar and 0.15 bar at the hypocenters of the Jiuzhaigou and Lushan earthquakes, respectively, both exceeding the threshold value ( 0.1 bar) of earthquake triggering (e.g., Ma et al. 2005). We also compute stress changes with frictions of 0.0, 0.4 and 0.8 (Additional file 1: Fig. S8) and the contribution of each stress component (shear stress and normal stress, Additional file 1: Fig. S9). At a certain depth, stress changes imparted by the Wenchuan earthquake at the hypocenters of the Jiuzhaigou and Lushan earthquakes decrease as $\mu^{\prime}$ increases, and most results exceed the threshold value. 

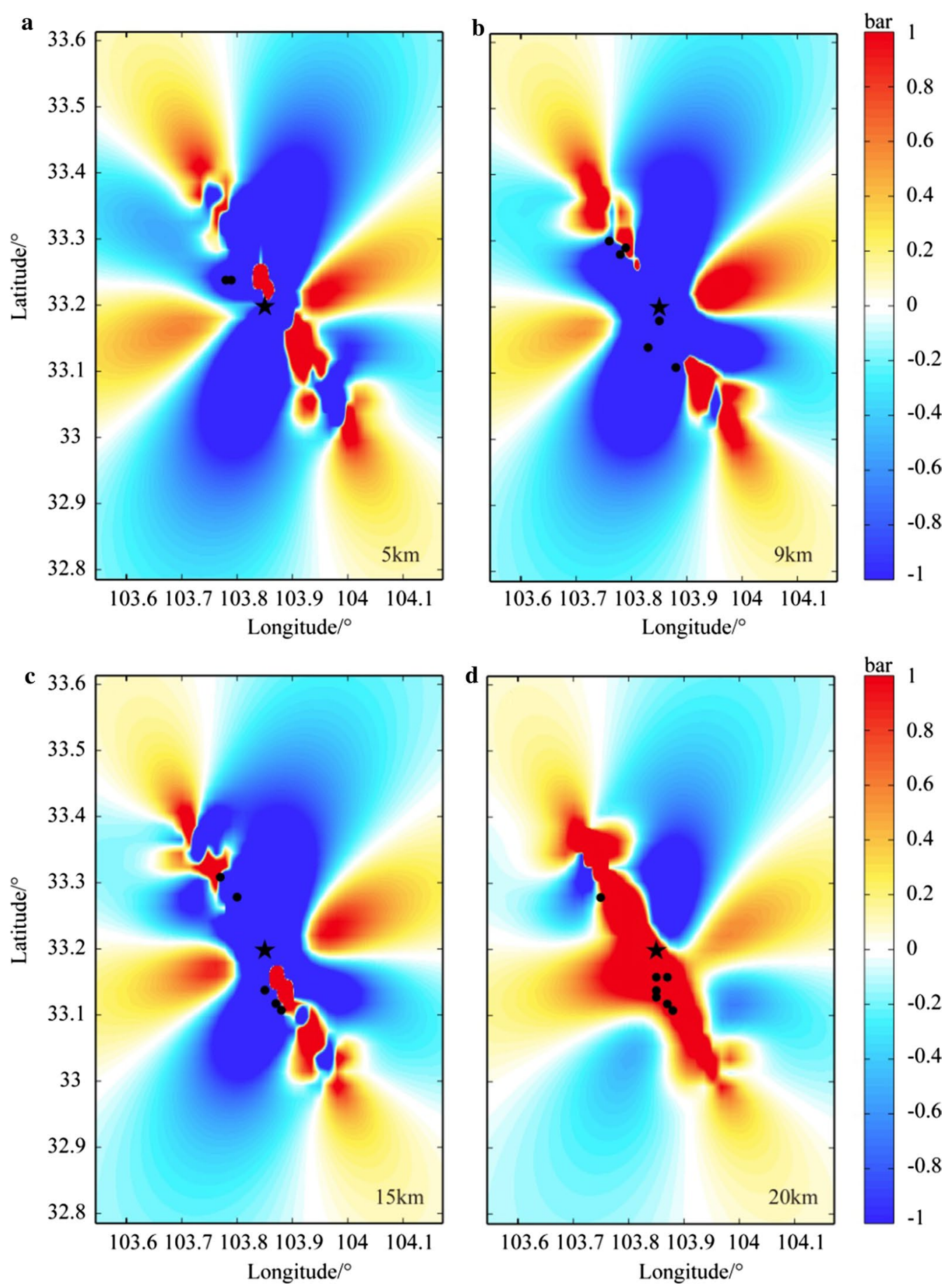

Fig. 4 Stress changes imparted by the 2017 Jiuzhaigou earthquake at different depths with an effective friction coefficient of 0.4 . a $5 \mathrm{~km}$, b $9 \mathrm{~km}$, c $15 \mathrm{~km}$ and $\mathbf{d} 20 \mathrm{~km}$. The black circles represent $\mathrm{M}_{\mathrm{L}} \geq 3$ aftershocks in 1 day after main-shock and their depths are limited between the calculated depths of $\pm 3 \mathrm{~km}$

\section{Discussion}

In this paper, our slip model of the Jiuzhaigou earthquake investigated with teleseismic body and surface waves inversion reveals the major features of this earthquake.
The results are in agreement with the surveys by several scholars (e.g., Xie et al. 2018; Zhang et al. 2018; Zhao et al. 2018). We concluded that the Jiuzhaigou earthquake is a left-lateral strike-slip event with a high dip angle and 
Table 5 Parameters of the major faults in the study area

\begin{tabular}{llllll}
\hline Fault & Strike & Dip & Rake & Slip rate (mm/year) & $\boldsymbol{\mu}^{\prime}$ \\
\hline MJ & $180^{\circ}$ & $45^{\circ}-56^{\circ}$ & $45^{\circ}$ & $<1$ & $0.6-0.8$ \\
HY & $150^{\circ}$ & $75^{\circ}$ & $45^{\circ}$ & 1.4 & $0.6-0.8$ \\
TZ & $100^{\circ}-145^{\circ}$ & $89^{\circ}$ & $0^{\circ}$ & - & $0.1-0.4$ \\
LRB & $205^{\circ}-209^{\circ}$ & $60^{\circ}$ & $135^{\circ}$ & $5.1 \pm 1.2$ & $0.4-0.6$ \\
DB & $290^{\circ}$ & $68-85^{\circ}$ & $45^{\circ}$ & - & $0.1-0.8$ \\
WX & $70^{\circ}$ & $70^{\circ}$ & $10^{\circ}$ & - & 0.4 \\
PQ & $70^{\circ}$ & $75^{\circ}$ & $-170^{\circ}$ & - & $0.6-0.8$ \\
WLQS & $30^{\circ}$ & $50^{\circ}$ & $90^{\circ}$ & - & 0.7 \\
MW & $205^{\circ}$ & $60^{\circ}$ & $142^{\circ}$ & - & 0.6 \\
BY & $205^{\circ}$ & $33^{\circ}$ & $142^{\circ}$ & $0.07-0.5$ & $0.6-0.8$ \\
PG & $200^{\circ}-207^{\circ}$ & $44^{\circ}$ & $94^{\circ}$ & $<1$ & $0.6-0.8$ \\
MEK & $145^{\circ}$ & $80^{\circ}$ & $10^{\circ}$ & $1.3 \pm 0.1$ & $0.6-0.8$ \\
\hline
\end{tabular}

consisted of the main rupture lasting about $15 \mathrm{~s}$. The rupture of the fault plane has a concentrated slip distribution around the hypocenter and no obvious directivity. Due to the little or no surface rupture, which is consistent with the InSAR, GPS observations (Nie et al. 2018) and field investigation (Xu et al. 2017a), the causative fault probably has not fully ruptured to reach the ground surface. It is likely that this earthquake initiated on a blind fault located in a complex tectonic area between the Huya, Minjiang and Tazang faults. There are some faults proposed to be the causative fault of the Jiuzhaigou earthquake, such as the Shuzheng fault located between the Minjiang and Tazang faults (Nie et al. 2018), the northern segment of the Huya fault (Sun et al. 2018; Zhang et al.
2018; Zhao et al. 2018) and a branch of the eastern Kunlun fault system (Han et al. 2018). In addition, Sun et al. (2018) advocated that this earthquake was presumably hosted by a "young" fault system located at the eastern end of the Kunlun fault system, and $\mathrm{Xu}$ et al. (2017b) inferred that the Huya fault triggered this earthquake. A single fault inversion can probably not fully describe the complexity of the rupture, and we need to use multiple faults (e.g., Sun et al. 2018) in the future.

The regional seismicity (Fig. 1) shows that several moderate earthquakes have struck the Minshan block over the last 400 years, most of them concentrated along the marginal faults, e.g., the Minjiang and Huya faults, resulting in a large accumulation of stress in this region. Moreover, the entire Huya fault has been broken through after the 1973 M6.5 Huanglong earthquake and the 1976 Songpan-Pingwu earthquake swarm (Yi et al. 2006). The Tazang fault in the eastern part of the East Kunlun fault has no large historic shock record. However, it may be at a stage of strain accumulation, according to regional GPS observation and the result of stress produced by the 2008 Wenchuan earthquake (Ren and Wang 2005; Shao et al. 2010). Notably, our studies indicate that the stresses imparted by the Jiuzhaigou earthquake on the Tazang fault, and the northern parts of the Minjiang and Huya faults (Fig. 5) exceed the threshold value of earthquake triggering ( $>0.1$ bar). In other words, the seismic hazard in these regions has probably increased due to the Jiuzhaigou earthquake.

Similarly, the resolved slip distribution of the Lushan earthquake implies that this earthquake is another thrust event in the Longmen Shan fault zone since the 2008

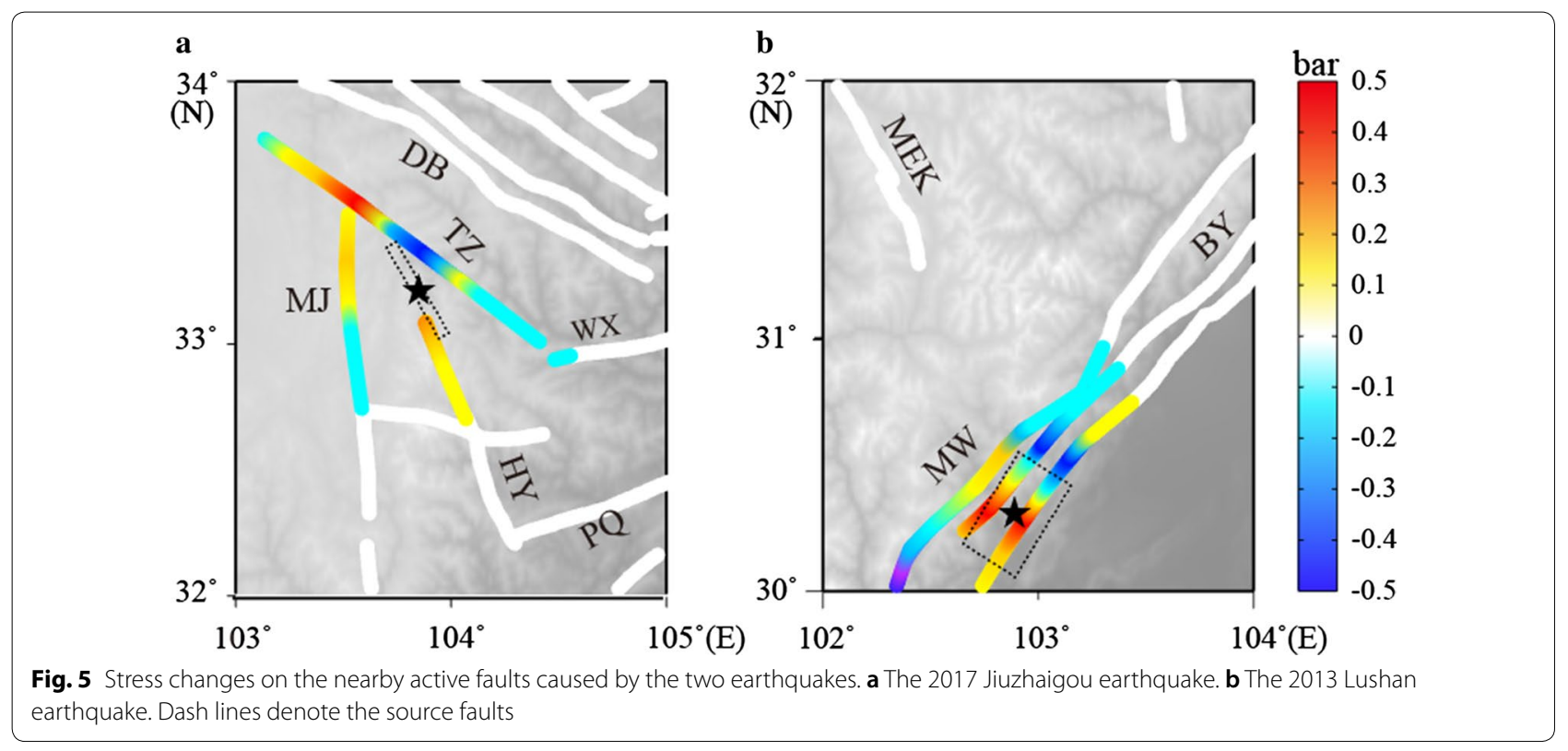



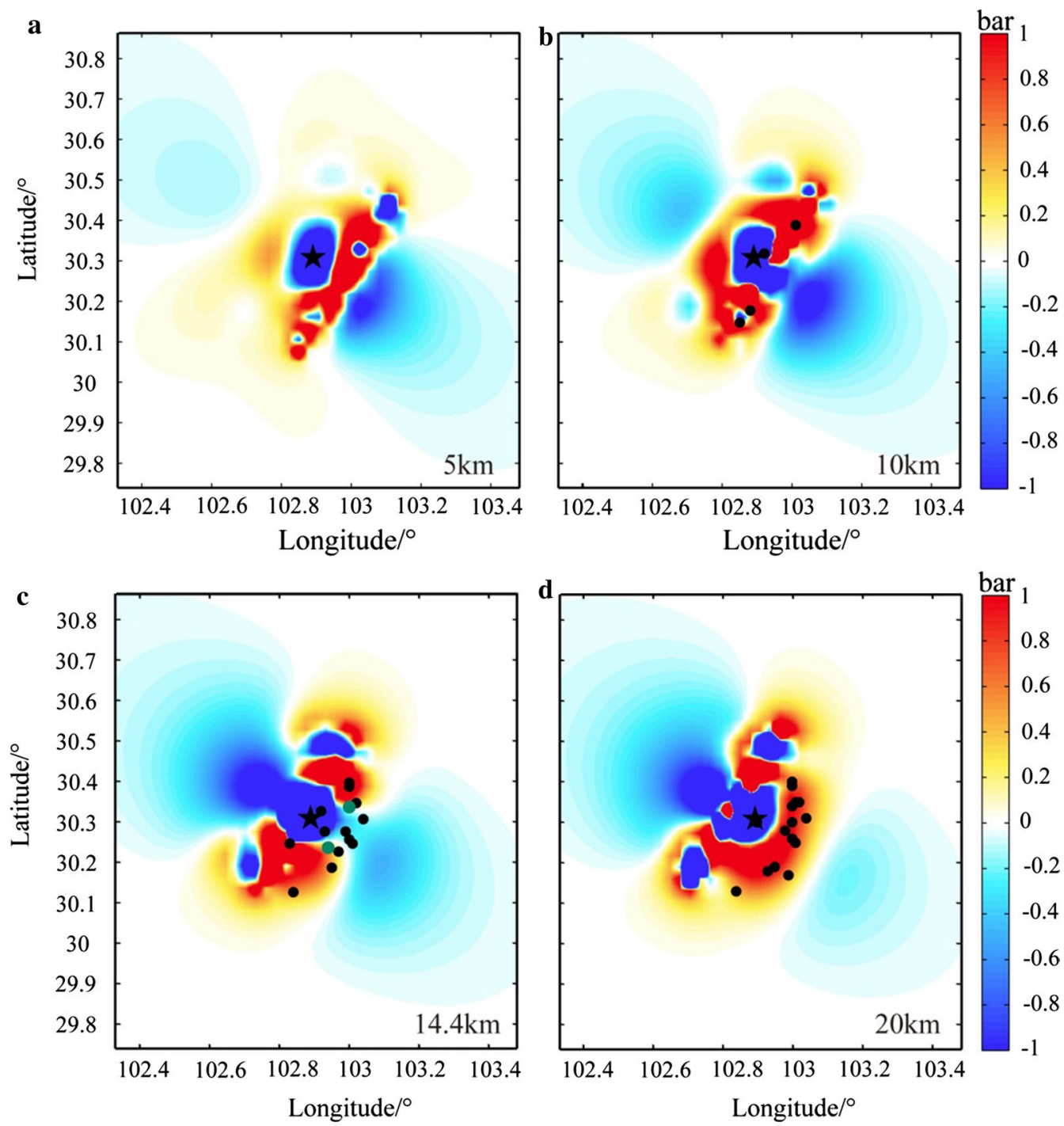

Fig. 6 Stress changes imparted by the 2013 Lushan earthquake at different depths with an effective friction coefficient of 0.4 . a $5 \mathrm{~km}, \mathbf{b} 10 \mathrm{~km}, \mathbf{c}$ $14.4 \mathrm{~km}$ and $\mathbf{d} 20 \mathrm{~km}$. The black circles represent $\mathrm{M}_{\mathrm{L}} \geq 4$ aftershocks in 1 day after main-shock and their depths are limited between the calculated depth of $\pm 3 \mathrm{~km}$. Grey circles in c are the two largest aftershocks (M 5.4)

Wenchuan earthquake, with a maximum slip near the hypocenter, and also might include two other rupture sub-events except for the main rupture in a depth of $\sim 20 \mathrm{~km}$ at $\sim 16 \mathrm{~s}$ (Fig. 3a), which is consistent with the previous studies (Liu et al. 2013; Wang et al. 2013; Zhang et al. 2013).

Blocked by the Sichuan Basin, the crustal material flow to the east caused the Longmen Shan region to become a seismically active zone. It is clear from the background seismicity (Fig. 1) that the central-northern segments of the Longmen Shan experience much more disastrous earthquakes, such as the Wenchuan earthquake, with massive rupture on its northern segment, which indicates that most of the energy accumulation has not been released on the southern portion of the Longmen Shan fault zone. Moreover, the Lushan earthquake functioned as a high-angle thrust event, after an extensive period of stress and strain accumulation (Zhu et al. 2008). Since this earthquake mainly affects stress changes on the Longmen Shan fault zone near the epicenter, such as the MW, BY and PG faults, it should be noted that their seismic potential must be investigated in the near future (Chen et al. 2013). Considering the calculated stress changes, our interpretation is that the Lushan earthquake might not have been related to the occurrence of the Jiuzhaigou earthquake. 


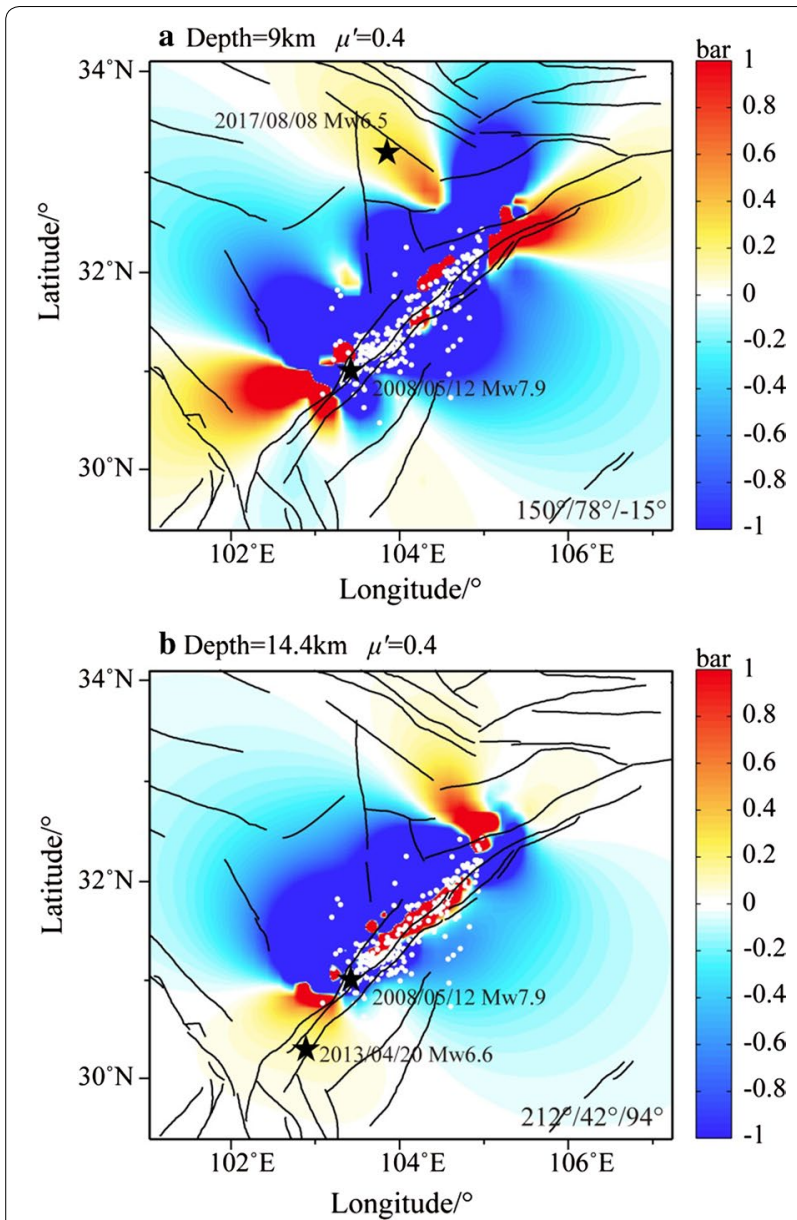

Fig. 7 Stress change imparted by the 2008 Wenchuan earthquake. a, b calculated at $9 \mathrm{~km}$ and $14.4 \mathrm{~km}$ depth with an effective friction coefficient of 0.4 , respectively. The black stars are the epicenters of the Jiuzhaigou and Lushan earthquakes, and the yellow star is the epicenter of the Wenchuan earthquake, while the black circles denote the Wenchuan earthquake $M_{\perp}>4$ aftershocks in 1 day after main-shock. The black lines indicate the major active faults in this region

Regarding the Coulomb stress change, the Wenchuan earthquake produced a significant impact on the surrounding area. The stress load on the southern segment of Longmen Shan fault zone has already reached or even surpassed the threshold for earthquake triggering (Parsons et al. 2008; Toda et al. 2008). In addition, our results indicate that the Lushan earthquake just occurs in the positive stress changes regions of the Wenchuan earthquake as well as the Jiuzhaigou earthquake. Of course, calculations of stress changes depend on the slip model, the receiver fault and other parameters, e.g., depth and effective friction coefficient, which leads to some differences in results (Parsons et al. 2008; Toda et al. 2008; Shan et al. 2013, 2017; Wang and Xu 2017). Nonetheless, it is observed that the stress increase in and around the epicentral areas of the Jiuzhaigou and Lushan earthquakes due to the Wenchuan earthquake was large enough for earthquake triggering in most cases (Fig. 7), which suggest that both the Jiuzhaigou and Lushan earthquakes were probably promoted by the 2008 Wenchuan earthquake.

\section{Conclusions}

In summary, our investigation of rupture processes and Coulomb stress changes of the $2017 M_{\mathrm{w}} 6.5$ Jiuzhaigou and $2013 M_{\mathrm{w}} 6.6$ Lushan earthquakes bring forth the following results:

1. The slip distribution of the $2017 M_{\mathrm{w}} 6.5$ strike-slip Jiuzhaigou earthquake is concentrated and showed no obvious directivity. The large-slip area was $\sim 20 \mathrm{~km}$ (along strike) with a depth range of $4-16 \mathrm{~km}$. The total seismic moment was $6.86 \times 10^{18} \mathrm{Nm}$, equivalent to an $M_{\mathrm{w}} 6.5$ earthquake.

2. The 2013 Lushan earthquake was another thrust event occurring in the Longmenshan fault zone after the 2008 Wenchuan earthquake. The rupture propagated from the hypocenter with an average velocity of $\sim 2.0 \mathrm{~km} / \mathrm{s}$. The peak slip was about $1.3 \mathrm{~m}$, while the seismic moment was $9.18 \times 10^{18} \mathrm{Nm}\left(M_{\mathrm{w}}=6.6\right)$.

3. The Tazang fault and the northern extremities of the Minjiang and Huya faults are strongly stressed following the Jiuzhaigou earthquake, beyond the threshold value for earthquake triggering, and the seismic hazard in these regions has increased.

4. Stress on the western extremities of the MaowenWenchuan, Beichuan-Yinxiu and Pengxian-Guanxian faults increased by $0.07,0.11$ and 0.26 bar, respectively, due to the Lushan earthquake. However, stress changes on the remote faults around the epicentral zone of the Jiuzhaigou earthquake were negligible, indicating that the Lushan earthquake may not have been related to the occurrence of the Jiuzhaigou earthquake.

5. The Wenchuan earthquake increased the stress up to 0.13 and 0.15 bar at the hypocenters of the Jiuzhaigou and Lushan earthquakes, respectively, in both cases above the threshold value for earthquake triggering. Therefore, we suggest that both the Jiuzhaigou and Lushan earthquakes were promoted by the 2008 Wenchuan earthquake. 


\section{Additional file}

Additional file 1: Fig. S1. Fit error of different focal mechanisms for the 2017 Jiuzhaigou earthquake. Fig. S2. Fit error of different focal mechanisms for the 2013 Lushan earthquake. Fig. S3. Fit error of different depths for the 2017 Jiuzhaigou earthquake (strike $150^{\circ}$, dip78 $8^{\circ}$, rake-13\%). Fig. S4. Fit error of different depths for the 2013 Lushan earthquake (strike $212^{\circ}$, dip $42^{\circ}$, rake $100^{\circ}$ ). Fig. S5. a. Map of relocated sequence of the 2013 Lushan earthquake, $\mathbf{b}$. depth cross section along AA'. The red dots denote aftershocks, whereas the main-shock is represented with the black star. Fig. S6. Histograms of aftershocks as the function of the value of stress change. a. The 2017 Jiuzhaigou earthquake and $\mathbf{b}$. The 2013 Lushan earthquake. Fig. S7. Stress changes imparted caused by the 2013 Lushan earthquake. a maximum Coulomb stress change, $\mathbf{b}$ stress change of the cross-sectional AB in a. Fig. S8. Stress changes imparted by the 2008 Wenchuan earthquake calculated with various depths and effective friction coefficients. $\mathbf{a}, \mathbf{b}$ and $\mathbf{c}$ are the calculations with effective friction coefficient of $0.0,0.4$ and 0.8 at $14 \mathrm{~km}$ depth, respectively. $\mathbf{d}$, $\mathbf{e}$ and $\mathbf{f}$ are the calculations with effective friction coefficient of $0.0,0.4$ and 0.8 at $9 \mathrm{~km}$ depth, respectively. The yellow star and black stars are the epicenters of the Wenchuan, Jiuzhaigou and Lushan earthquakes, and black circles denote the Wenchuan earthquake 1 day $M_{L}>4$ aftershocks. Fig. S9. Shear and normal stress changes imparted by the 2008 Wenchuan earthquake. $\mathbf{a}, \mathbf{b}$ are the calculations at $9 \mathrm{~km}$ depth. $\mathbf{c}, \mathbf{d}$ are the calculations at $14.4 \mathrm{~km}$ depth.

\section{Acknowledgements}

The teleseismic data were downloaded from the Data Management Center (DMC) of the Incorporated Research Institutions for Seismology (http://www iris.edu). We used the Generic Mapping Tools (GMT) software for drawing the figures (Wessel and Smith 1998).

\section{Authors' contributions}

$\mathrm{XL}$ conducted the inversion, calculated coseismic Coulomb stress changes and drafted the manuscript. RC participated in the design and helped to draft the manuscript. XZ analyzed the data and participated in discussion of the study. All authors read and approved the final manuscript.

\section{Funding}

This research was financially supported by the Strategic Priority Research Program (B) of Chinese Academy of Sciences (Grant XDB18000000) and Major Program of National Natural Science Foundation of China (Grant 41590854).

\section{Availability of data and materials}

The teleseismic data for this study are provided by the Incorporated Research Institutions for Seismology. Teleseismic data are available through the Data Management Center (https://ds.iris.edu/ds/nodes/dmc/). The velocity and slip models of the 2008 Wehchuan earthquake are provided by Ji and Hayes (2008) and are available online (http://earthquake.usgs.gov/eqcenter/eqint henews/2008/us2008ryan/finite_fault.php).

\section{Competing interests}

The authors declare that they have no competing interests.

Received: 27 February 2019 Accepted: 21 July 2019

Published online: 30 July 2019

\section{References}

Avouac JP, Ayoub F, Wei SJ et al (2014) The 2013, Mw7.7 Balochistan earthquake, energetic strike-slip reactivation of a thrust fault. Earth Planet Sci Lett 391:128-134

Barka A (1999) The 17 August 1999 Izmit earthquake. Science 285(5435):1858-1859

Bassin C, Laske G, Masters G (2000) The current limits of resolution for surface wave tomography in North America. EOS Trans AGU 81:897
Bouchon M (1997) The state of stress on some faults of the San Andreas system as inferred from near-field strong motion data. J Geophys Res Solid Earth 102(B6):11731-11744

Burchfiel BC, Chen ZL, Liu Y et al (1995) Tectonics of the Longmen Shan and adjacent regions, China. Int Geol Rev 37(8):661-735

Chen Z, Burchfiel BC, Liu Y et al (2000) Global Positioning System measurements from eastern Tibet and their implications for India/ Eurasia intercontinental deformation. J Geophys Res Solid Earth 105(B7):16215-16227

Chen YT, Yang ZX, Zheng Y et al (2013) From 2008 Wenchuan earthquake to 2013 Lushan earthquake. Sci China Earth Sci 43:1064-1072 (in Chinese)

Cocco M, Rice JR (2002) Pore pressure and poroelasticity effects in Coulomb stress analysis of earthquake interactions. J Geophys Res. https://doi. org/10.1029/2000JB000138

Das S, Scholz CH (1981) Off-fault aftershock clusters caused by shear stress increase? Bull Seismol Soc Am 71(5):1669-1675

Deng QD, Zhang PZ, Ran YK et al (2003a) Active tectonics and earthquake activities in China. Earth Sci Front 10(SUPP):66-73 (in Chinese with English abstract)

Deng QD, Zhang PZ, Ran YK et al (2003b) Basic characteristics of active tectonics of China. Sci China Earth Sci 46(4):356-372

Department of Earthquake Disaster Prevention, China Earthquake Administration (1995) The catalogue of chinese historical strong earthquakes. Seismological Press, Beijing (in Chinese)

Department of Earthquake Disaster Prevention, China Earthquake Administration (1999) The catalogue of chinese modern earthquakes. Seismological Press, Beijing (in Chinese)

Dziewonski AM, Anderson DL (1981) Preliminary reference Earth model. Phys Earth Planet Inter 25(4):297-356

Freed AM (2005) Earthquake triggering by static, dynamic, and postseismic stress transfer. Annu Rev Earth Planet Sci 33:335-367

Hainzl S, Brietzke GB, Zöller G (2010) Quantitative earthquake forecasts resulting from static stress triggering. J Geophys Res Solid Earth. https://doi. org/10.1029/2010JB007473

Han LB, Zeng XF, Jiang CS et al (2014) Focal mechanisms of the 2013 Mw 6.6 Lushan, China earthquake and high-resolution aftershock relocations. Seismol Res Lett 85(1):8-14. https://doi.org/10.1785/0220130083

Han LB, Cheng J, An YR et al (2018) Preliminary Report on the 8 August 2017 Ms7.0 Jiuzhaigou, Sichuan, China, Earthquake. Seismol Res Lett 89(2A):557-569. https://doi.org/10.1785/0220170158

Hao JL, Ji C, Wang WM et al (2013) Rupture history of the 2013 Mw6.6 Lushan earthquake constrained with local strong motion and teleseismic body and surface waves. Geophys Res Lett 40(20):5371-5376

Harris RA (1998) Introduction to special section: stress triggers, stress shadows, and implications for seismic hazard. I Geophys Res Solid Earth 103:24347-24358. https://doi.org/10.1029/98JB01576

Hartzell SH, Heaton TH (1983) Inversion of strong ground motion and teleseismic waveform data for the fault rupture history of the 1979 Imperial Valley, California, earthquake. Bull Seismol Soc Am 73:1553-1583

Hartzell S, Liu PC (1996) Calculation of earthquake rupture histories using a hybrid global search algorithm: application to the 1992 Landers, California, earthquake. Phys Earth Planet Inter 95(1-2):79-99

Hashimoto M, Enomoto M, Fukushima Y (2010) Coseismic deformation from the 2008 Wenchuan, China, earthquake derived from ALOS/PALSAR images. Tectonophysics 491(1-4):59-71. https://doi.org/10.1016/j.tecto .2009 .08 .034

He JK, Chéry J (2008) Slip rates of the Altyn Tagh, Kunlun and Karakorum faults (Tibet) from 3D mechanical modeling. Earth Planet Sci Lett 274(1-2):50-58

Helmstetter A, Shaw BE (2006) Relation between stress heterogeneity and aftershock rate in the rate-and-state model. J Geophys Res Solid Earth. https://doi.org/10.1029/2005JB004077

Helmstetter A, Yan YK, Jackson DD (2005) Importance of small earthquakes for stress transfers and earthquake triggering. J Geophys Res Solid Earth 110:1649-1650. https://doi.org/10.1029/2004JB003286

Hill DP, Reasenberg PA, Michael A et al (1993) Seismicity remotely triggered by the magnitude 7.3 Landers, California, Earthquake. Science 260:1617-1623

Hu JH, Fu LY, Sun WJ et al (2017) A study of the Coulomb stress and seismicity rate changes induced by the 2008 Mw7.9 Wenchuan earthquake, SW 
China. J Asian Earth Sci 135:303-319. https://doi.org/10.1016/j.jseae s.2016.12.048

Huang Q (2008) Seismicity changes prior to the Ms8.0 Wenchuan earthquake in Sichuan, China. Geophys Res Lett 35:L23308. https://doi. org/10.1029/2008GL036270

Ishibe T, Satake K, Sakai S et al (2015) Correlation between Coulomb stress imparted by the 2011 Tohoku-Oki earthquake and seismicity rate change in Kanto, Japan. Geophys J Int 201(1):112-134

Ji C, Hayes G (2008) Preliminary result of the May 12, 2008 Mw7.9 eastern Sichuan. https://earthquake.usgs.gov/eqcenter/eqinthenews/2008/ us2008ryan/finite_fault.php

Ji C, Wald DJ, Helmberger DV (2002) Source description of the 1999 Hector Mine, California, earthquake, part l: wavelet domain inversion theory and resolution analysis. Bull Seismol Soc Am 92(4):1192-1207

$\mathrm{Ji}$ C, Helmberger DV, Wald DJ et al (2003) Slip history and dynamic implications of the 1999 Chi-Chi, Taiwan, earthquake. J Geophys Res Solid Earth. https://doi.org/10.1029/2002JB001764

Jia K, Zhou SY, Zhuang JC et al (2018) Did the 2008 Mw 7.9 Wenchuan earthquake trigger the occurrence of the 2017 Mw 6.5 Jiuzhaigou earthquake in Sichuan, China? J Geophys Res Solid Earth 123(4):2965-2983

Jones LM, Han W, Hauksson E et al. (1984) Focal mechanisms and aftershock locations of the Songpan earthquakes of August 1976 in Sichuan, China. J Geophys Res Solid Earth 89(B9):7697-7707. https://doi. org/10.1029/JB089iB09p07697

Kanamori H (1977) The energy release in great earthquakes. J Geophys Res 82(20):2981-2987

King GCP, Stein RS, Lin J (1994) Static stress changes and the triggering of earthquakes. Bull Seismol Soc Am 84(3):935-953

Kirby E, Whipple KX, Burchfiel BC et al (2000) Neotectonics of the Min Shan, China: implications for mechanisms driving Quaternary de-formation along the eastern margin of the Tibetan Plateau. Geol Soc Am Bull 112(3):375-393

Kirby E, Harkins N, Wang E et al (2007) Slip rate gradients along the eastern Kunlun fault. Tectonics. https://doi.org/10.1029/2006TC002033

Lay T, Ammon CJ, Kanamori H et al (2010) Teleseismic inversion for rupture process of the 27 February 2010 Chile (Mw8.8) earthquake. Geophys Res Lett. https://doi.org/10.1029/2010GL043379

Lin J, Stein RS (2004) Stress triggering in thrust and subduction earthquakes and stress interaction between the southern San Andreas and nearby thrust and strike-slip faults. J Geophys Res Solid Earth. https://doi. org/10.1029/2003JB002607

Liu CL, Zheng Y, Ge C et al (2013) Rupture Process of the M7.0 Lushan Earthquake. Sci China Earth Sci 1:1. https://doi.org/10.1007/s11430-0134639-9 (in Chinese with English abstract)

Luo G, Liu M (2010) Stress evolution and fault interactions before and after the 2008 Great Wenchuan earthquake. Tectonophysics 491:127-140. https ://doi.org/10.1016/j.tecto.2009.12.019

Ma KF, Chan CH, Stein RS (2005) Response of seismicity to Coulomb stress triggers and shadows of the $1999 \mathrm{M}_{\mathrm{w}}=7.6 \mathrm{Chi}$-Chi, Taiwan, earthquake. J Geophys Res. https://doi.org/10.1029/2004JB003389

Marsan D, Lengline O (2008) Extending earthquakes' reach through cascading. Science 319(5866):1076-1079

Nalbant SS, Mccloskey J (2011) Stress evolution before and after the 2008 Wenchuan, China earthquake. Earth Planet Sci Lett 307:222-232. https ://doi.org/10.1016/j.epsl.2011.04.039

Nie ZS, Wang DJ, Jia ZG et al (2018) Fault model of the 2017 Jiuzhaigou Mw 6.5 earthquake estimated from coseismic deformation observed using global positioning system and interferometric synthetic aperture radar data. Earth Planets Space 70(1):55. https://doi.org/10.1186/s4062 3-018-0826-4

Nostro C, Chiaraluce L, Cocco M et al (2005) Coulomb stress changes caused by repeated normal faulting earthquakes during the 1997 UmbriaMarche (central Italy) seismic sequence. J Geophys Res Solid Earth 110:2156-2202. https://doi.org/10.1029/2004JB003386

Ogata Y (2005) Detection of anomalous seismicity as a stress change sensor. J Geophys Res Solid Earth. https://doi.org/10.1029/2004JB003245

Okada Y (1992) Internal deformation due to shear and tensile faults in a halfspace. Bull Seismol Soc Am 82(2):1018-1040

Olson AH, Apsel RJ (1982) Finite faults and inverse theory with applications to the 1979 Imperial Valley earthquake. Bull Seismol Soc Am 72(6A):1969-2001
Parsons T, Segou M (2014) Stress, distance, magnitude, and clustering influences on the success or failure of an aftershock forecast: the 2013 M 6.6 Lushan earthquake and other examples. Seismol Res Lett 85(1):44-51. https://doi.org/10.1785/0220130100

Parsons T, Stein RS, Simpson RW et al (1999) Stress sensitivity of fault seismicity: a comparison between limited-offset oblique and major strike slip faults. J Geophys Res 104:20183-20202. https://doi.org/10.1029/1999J B900056

Parsons T, Yeats RS, Yagi Y et al (2006) Static stress change from the 8 October, $2005 M=7.6$ Kashmir earthquake. Geophys Res Lett 33:429-453. https ://doi.org/10.1029/2001JB000646

Parsons T, Ji C, Kirby E (2008) Stress changes from the 2008 Wenchuan earthquake and increase hazard in the Sichuan basin. Nature 454:509-510

Pollitz F, Vergnolle M, Calais E (2003) Fault interaction and stress triggering of twentieth century earthquakes in Mongolia. J Geophys Res 108:2503

Reasenberg PA, Simpson RW (1992) Response of regional seismicity to the static stress change produced by the Loma Prieta earthquake. Science 255:1687-1690. https://doi.org/10.1126/science.255.5052.1687

Ren JW, Wang M (2005) GPS measured crustal deformation of the Ms8.1 Kunlun earthquake on November 14th 2001 in Qinghai-Xizang plateau. Quat Sci 25:34-44 (in Chinese with English abstract)

Ren JJ, Xu XW, Yeats RS et al (2013) Millennial slip rates of the Tazang fault, the eastern termination of Kunlun fault: implications for strain partitioning in eastern Tibet. Tectonophysics 608:1180-1200

Rice JR, Cleary MP (1976) Some basic stress diffusion solutions for fluidsaturated elastic porous media with compressible constituents. Rev Geophys 14(2):227-241

Shan B, Xiong X, Zheng Y et al (2013) Stress changes on major faults caused by 2013 Lushan earthquake, and its relationship with 2008 Wenchuan earthquake. Sci China Earth Sci 56(7):1169-1176. https://doi. org/10.1007/s11430-013-4642-1

Shan B, Zheng Y, Liu CL et al (2017) Coseismic Coulomb failure stress changes caused by the 2017 M7.0 Jiuzhaigou earthquake, and its relationship with the 2008 Wenchuan earthquake. Sci China Earth Sci 60(12):21812189. https://doi.org/10.1007/s11430-017-9125-2

Shao ZG, Zhou LQ, Jiang CS et al (2010) The impact of Wenchuan Ms8.0 earthquake on the seismic activity of surrounding faults. Chin I Geophys 53(8):1784-1795. https://doi.org/10.3969/j.issn.0001-5733.2010.08.004 (in Chinese with English abstract)

Shao GF, Li XY, Ji C et al (2011) Focal mechanism and slip history of the 2011 $M_{w} 9.1$ off the Pacific coast of Tohoku Earthquake, constrained with teleseismic body and surface waves. Earth Planets Space 63(7):559-564

Shen ZK, Sun J, Zhang PZ et al (2009) Slip maxima at fault junctions and rupturing of barriers during the 2008 Wenchuan earthquake. Nat Geosci 2:718-724. https://doi.org/10.1038/ngeo636

Steacy S, Marsan D, Nalbant SS et al (2004) Sensitivity of static stress calculations to the earthquake slip distribution. J Geophys Res Solid Earth. https://doi.org/10.1029/2002JB002365

Steacy S, Gomberg J, Cocco M (2005) Introduction to special section: stress transfer, earthquake triggering, and time-dependent seismic hazard. J Geophys Res. https://doi.org/10.1029/2005JB003692

Stein RS (1999) The role of stress transfer in earthquake occurrence. Nature 402:605-609

Stein RS, Lisowski M (1983) The 1979 Homestead Valley earthquake sequence, California: control of aftershocks and postseismic deformation. J Geophys Res Solid Earth 88(B8):6477-6490

Stein RS, King GCP, Lin J (1992) Change in failure stress on the southern San Andreas fault system caused by the 1992 magnitude $=7.4$ Landers earthquake. Science 258(5086):1328-1332

Sun JB, Yue H, Shen ZK et al (2018) The 2017 Jiuzhaigou earthquake: a complicated event occurred in a young fault system. Geophys Res Lett 45:2230-2240. https://doi.org/10.1002/2017GL076421

Tibi R, Wiens DA, Inoue H (2003) Remote triggering of deep earthquakes in the 2002 Tonga sequences. Nature 424:921-925

Toda S (2008) Coulomb stresses imparted by the 25 March 2007 Mw $=6.6$ Noto-Hanto, Japan, earthquake explain its 'butterfly' distribution of aftershocks and suggest a heightened seismic hazard. Earth Planets Space 60(10):1041-1046. https://doi.org/10.1186/BF03352866

Toda S, Stein RS, Reasenberg PA et al (1998) Stress transferred by the 1995 $M_{w}=6.9$ Kobe, Japan, shock: effect on aftershocks and future 
earthquake probabilities. J Geophys Res Solid Earth 103(B10):2454324565. https://doi.org/10.1029/98JB00765

Toda S, Lin J, Meghraoui M et al (2008) 12 May 2008 M=7.9 Wenchuan, China, earthquake calculated to increase failure stress and seismicity rate on three major fault systems. Geophys Res Lett 35:17

Toda S, Stein RS, Beroza GC et al (2012) Aftershocks halted by static stress shadows. Nat Geosci 5:410-413. https://doi.org/10.1038/ngeo1465

Wan YG, Shen ZK (2010) Static Coulomb stress changes on faults caused by the 2008 Mw7.9 Wenchuan, China earthquake. Tectonophysics 491(1-4):105-118

Wang JJ, Xu CJ (2017) Coseismic Coulomb stress changes associated with the 2017 Mw6.5 Jiuzhaigou earthquake (China) and its impacts on surrounding major faults. Chin J Geophys 60(11):4398-4420. https://doi. org/10.6038/cjg20171127 (in Chinese with English abstract)

Wang WM, He YM, Yao ZX (2004) Complexity of the coseismic rupture for 1999 Chi-Chi Earthquake (Taiwan) from inversion of GPS observations. Tectonophysics 382:151-172

Wang Q, Qiao X, Lan Q et al (2011) Rupture of deep faults in the 2008 Wenchuan earthquake and uplift of the Longmen Shan. Nat Geosci 4(9):634-640

Wang WM, Hao JL, Yao ZX (2013) Preliminary result for rupture process of Apr. 20, 2013, Lushan earthquake, Sichuan, China. Chin J Geophys 56(4):1412-1417. https://doi.org/10.6038/cjg20130436 (in Chinese with English abstract)

Wei SJ, Helmberger DV, Zhan ZW et al (2013) Rupture complexity of the Mw 8.3 sea of okhotsk earthquake: rapid triggering of complementary earthquakes? Geophys Res Lett 40(19):5034-5039

Wessel P, Smith WH (1998) New, improved version of generic mapping tools released. EOS Trans Am Geophys Union 79(47):579-678

Xie CD, Zhu YQ, Lei XL et al (2010) Pattern of stress change and its effect on seismicity rate caused by Ms8.0 Wenchuan earthquake. Sci China Earth Sci 53:1260-1270. https://doi.org/10.1007/s11430-010-4025-9

Xie Z, Zheng Y, Yao H et al (2018) Preliminary analysis on the source properties and seismogenic structure of the 2017 Ms 7.0 Jiuzhaigou earthquake. Sci China Earth Sci 61 (3):339-352

Xiong X, Shan B, Zheng Y et al (2010) Stress transfer and its implication for earthquake hazard on the Kunlun Fault, Tibet. Tectonophysics 482:216-225

Xu CJ, Wang JJ, Li ZH et al (2010) Applying the Coulomb failure function with an optimally oriented plane to the 2008 Mw7.9 Wenchuan earthquake triggering. Tectonophysics 491(1-4):119-126

Xu XW, Chen GH, Wang QX et al (2017a) Discussion on seismogenic structure of Jiuzhaigou earthquake and its implication for current strain state in the southeastern Qinghai-Tibet Plateau. Chin J Geophys 60(10):40184026. https://doi.org/10.6038/cjg20171028 (in Chinese with English abstract)
Xu X, Gao R, Guo XY et al (2017b) Outlining tectonic inheritance and construction of the Min Shan region, eastern Tibet, using crustal geometry. Sci Rep 7(1):13798. https://doi.org/10.1038/s41598-017-14354-4

Yagi Y, Okuwaki R, Enescu B et al (2016) Rupture process of the 2016 Kumamoto earthquake in relation to the thermal structure around Aso volcano. Earth Planets Space 68(1):118

Ye LL, Lay T, Kanamori H et al (2016) Rapidly estimated seismic source parameters for the 16 September 2015 Illapel, Chile Mw8.3 earthquake. Pure Appl Geophys 173(2):321-332

Yi GX, Wen XZ, Wang SW et al (2006) Study on fault sliding behaviors and strong-earthquake risk of the Longmenshan-Minshan fault zones from current seismicity parameters. Earthq Res China 22(2):117-125 (in Chinese with English abstract)

Zhang JL, Ren JW, Fu JD (2012) Earthquake rupture features and tectonic significance of the Tazang fault in the eastern part of the East Kunlun Fault Zones. Earthquake 32(1):1-16 (in Chinese with English abstract)

Zhang Y, Xu LS, Chen YT (2013) Rupture process of the Lushan 4.20 earthquake and preliminary analysis on the disaster-causing mechanism. Chin J Geophys 56(4):1408-1411. https://doi.org/10.6038/cjg20130435 (in Chinese with English abstract)

Zhang X, Zha X, Dai Z (2015) Stress changes induced by the 2008 Wenchuan earthquake, China. J Asian Earth Sci 98:98-104. https://doi. org/10.1016/j.jseaes.2014.10.001

Zhang YF, Zhang GH, Hetland EA et al (2018) Source fault and slip distribution of the 2017 Mw 6.5 Jiuzhaigou, China, Earthquake and Its Tectonic Implications. Seismol Res Lett 89(4):1345-1353. https://doi. org/10.1785/0220170255

Zhao DZ, Qu CY, Shan XJ et al (2018) InSAR and GPS derived coseismic deformation and fault model of the 2017 Ms 7.0 Jiuzhaigou earthquake in the Northeast Bayanhar block. Tectonophysics 726:86-99. https://doi. org/10.1016/j.tecto.2018.01.026

Zhou RJ, Pu XH, He YL et al (2000) Recent activity of Minjiang fault zone, uplift of Minshan block and their relationship with seismicity of Sichuan. Seismol Geol 22(3):285-294 (in Chinese with English abstract)

Zhu JS (2008) The Wenchuan earthquake occurrence background in deep structure and dynamics of lithosphere. J Cheng Univ Technol 35(4):348356 (in Chinese with English abstract)

Zhuang JC, Chang CP, Ogata Y et al (2005) A study on the background and clustering seismicity in the Taiwan region by using point process models. J Geophys Res 110:18. https://doi.org/10.1029/2004JB003157

\section{Publisher's Note}

Springer Nature remains neutral with regard to jurisdictional claims in published maps and institutional affiliations.

\section{Submit your manuscript to a SpringerOpen ${ }^{\circ}$ journal and benefit from:}

- Convenient online submission

- Rigorous peer review

- Open access: articles freely available online

- High visibility within the field

- Retaining the copyright to your article

Submit your next manuscript at $\boldsymbol{\nabla}$ springeropen.com 